\title{
Reduksi Informasi Hoax di Era Digital Melalui Pendidikan Karakter Berbasis Pancasila
}

\author{
Armaidy Armawi \\ Universitas Gadjah Mada Yogyakarta \\ Email: armaidy@ugm.ac.id
}

\begin{abstract}
ABSTRAK
Informasi sudah menjadi suatu kebutuhan utama bagi warga negara, namun fenomenanya ialah tidak semua informasi yang beredar di masyarakat ialah fakta, bisa jadi baru opini, atau bahkan suatu informasi yang tidak benar. Perkembangan teknologi informasi dan komunikasi secara langsung maupun tidak langsung memberikan dampak positif dan negatif di masyarakat. Adapun tujuan dari penelitian ini yaitu untuk mengetahui proses pendidikan karakter berbasis Pancasila di era digital. Penelitian ini menggunakan metode penelitian lapangan dan termasuk jenis penelitian deskriptif. Hasil penelitian menunjukkan bahwa pendidikan karakter berbasis Pancasila di era digital di HMP Demokratia PPKn FKIP UNS, Surakarta dilakukan dengan kegiatan peningkatan literasi mahasiswa melalui berbagai kegiatan seperti seminar, FGD, dan kelas kebangsaan. Adapun proses mereduksi informasi hoax dilakukan dengan cara cross check information, dan pendidikan karakter yang dilakukan melalui diskusi publik dengan dewan dosen. Literasi warga negara dalam hal berkewarganegaraan umumnya di dunia nyata, khususnya di dunia maya, sangat perlu diperhatikan. Salah satu cara membangun literasi kewarganegaraan tersebut melakukan reaktualisasi nilai-nilai Pancasila baik dalam kehidupan nyata maupun kehidupan maya yang pada saat ini sudah menjadi bagian dari kehidupan warganegara. Kemampuan literasi teknologi informasi dan komunikasi merupakan hal yang sangat penting dan diperlukan masyarakat dalam rangka menghadapi kemajuan era digital saat ini. Dengan literasi saja tidak cukup, untuk itu negara perlu memperkuat dengan nilai-nilai yang sudah dibangun sejak lama yaitu nilai-nilai Pancasila. Negara perlu memastikan bahwa nilai-nilai tersebut dipraktikkan untuk mencegah hal-hal yang dapat merugikan masyarakat pada umumnya.
\end{abstract}

Kata kunci: Reduksi, Informasi Hoax, Pendidikan Karakter Pancasila.

\section{PENDAHULUAN}

\section{Perkembangan teknologi}

informasi dan komunikasi secara langsung maupun tidak langsung telah berdampak pada masyarakat di Indonesia. Perkembangan teknologi informasi dan komunikasi juga dianggap sebagai suatu kemajuan zaman sehingga penyesuaian perlu dilakukan oleh masyarakat guna beradaptasi dengan perkembangan teknologi informasi dan komunikasi tersebut. Satu sisi perkembangan teknologi informasi dan komunikasi merupakan suatu kemajuan ilmu pengetahuan, namun di sisi lain pemahaman pengetahuan tentang teknologi informasi itu sendiri harus terus ditingkatkan di kalangan masyarakat. Hal ini dikarenakan selalu ada dampak baik positif maupun negatif dari adanya perkembangan teknologi informasi dan komunikasi. Pengetahuan tentang pemahaman ini yang disebut sebagai literasi teknologi informasi. 
Secara umum, tingkat literasi di Indonesia sangat rendah. Penelitian yang dilakukan oleh Programme for International Student Assessment (PISA) pada 2012 menunjukkan data bahwa Indonesia menduduki peringkat 60 dengan skor 396 dari total 65 peserta negara untuk kategori membaca. Hasil ukur membaca ini mencakup memahami, menggunakan, dan merefleksikan dalam bentuk tulisan. Skor rata-rata internasional yang ditetapkan oleh PISA sendiri sebesar 500. Capaian itu tentu turun dibandingkan peringkat Indonesia pada 2009 di urutan 57 dengan skor 402 dari total 65 negara. Pada tahun tersebut, skornya memang naik tetapi peringkatnya turun. Indonesia menduduki peringkat membaca 48 dengan skor 393 dari 56 negara pada 2006. Di negara Asia Tenggara, kemampuan terbaik literasi membaca pada penelitian PISA tahun 2012 dipegang oleh Singapura yang menduduki peringkat ke 3 dengan perolehan skor 542. Adapun negara tetangga Malaysia ada di atas Indonesia dengan peringkat 59 dengan skor 398.

Rendahnya literasi membaca Indonesia tersebut dapat dikaitkan dengan angka buta huruf di Indonesia yang masih tinggi. Di era teknologi dan informasi yang masif seperti sekarang, tetap tidak menyingkirkan fakta bahwa jutaan penduduk Indonesia masih ada yang buta huruf. Berdasarkan data Pusat Data dan Statistik Kemendikbud tahun 2015, angka buta huruf di Indonesia masih tinggi yang jumlahnya mencapai 5.984.075 orang. Ini tersebar di enam provinsi meliputi Jawa Timur 1.258.184 orang, Jawa Tengah 943.683 orang, Jawa Barat 604.683 orang, Papua 584.441 orang, Sulawesi Selatan 375.221 orang, Nusa Tenggara Barat 315.258 orang. Secara persentase, Papua menduduki angka tertinggi. Demikian pula Nusa Tenggara. Adapun persentase buta huruf terendah dipegang oleh DKI Jakarta.

Secara keseluruhan, Indonesia memiliki persentase buta huruf sebesar 4,78 persen untuk usia 15 tahun ke atas, 1,10 persen untuk usia 14-44 tahun dan 11,89 persen untuk usia 45 tahun ke atas. Perolehan tersebut berdasarkan data terakhir mengenai persentase buta huruf pada tahun 2015 yang diselenggarakan oleh Badan Pusat Statistik (BPS). Literasi tampaknya belum sepenuhnya dipeluk sebagai suatu budaya yang beriringan dengan kehidupan sehari-hari. Fenomena ini juga dapat dilihat di lingkungan sekitar, kebiasaan seperti membaca buku di tempat umum masih langka dijumpai. Padahal, di era globalisasi ini, perkembangan teknologi informasi dan komunikasi dirasakan begitu cepat dan menjadi salah satu kebutuhan bagi masyarakat, utamanya dalam hal akses informasi.

Perkembangan teknologi informasi dan komunikasi (TIK atau 
yang biasa juga disebut dengan ICT) ini telah membuat semakin banyak pihak menyadari bahwa masalah utama yang dihadapi bukan hanya bagaimana mendapatkan akses terhadap informasi tapi lebih pada bagaimana memilih informasi yang sesuai dengan kebutuhan secara selektif. Usaha untuk memilih informasi ternyata lebih besar dari pada sekedar mendapat akses terhadap informasi (Mandala \& Setiawan, 2002). Perkembangan teknologi informasi dan komunikasi yang pesat juga berdampak pada penelusuran sumber informasi berbasis elektronik sebagai sebuah pekerjaan yang cukup rumit bagi pengguna yang belum terbiasa berinteraksi dengan sumber-sumber tersebut. Hal tersebut berdampak pula pada dokumen yang dapat ditemukan serta relevansi sumber dokumen dengan kebutuhan informasi. Terkait dengan perkembangan teknologi informasi dan komunikasi, khususnya pada bidang perkembangan internet, dapat dilihat pada data statistik pengguna internet di Indonesia. melalui survei yang telah dilakukan oleh Asosiasi Penyelenggara Jasa Internet Indonesia (APJII) telah mengumumkan hasil survei Data Statistik Pengguna Internet Indonesia tahun 2016. Jumlah pengguna Internet di Indonesia tahun 2016 yaitu 132,7 juta user atau sekitar 51,5\% dari total jumlah penduduk Indonesia sebesar 256,2 juta. Pengguna internet terbanyak ada di pulau Jawa dengan total pengguna 86.339.350 user atau sekitar $65 \%$ dari total penggunan Internet. Jika dibandingkan penggunana Internet Indonesia pada tahun 2014 sebesar 88,1 juta user, maka terjadi kenaikkan sebesar 44,6 juta dalam waktu 2 tahun (2014 2016). Pengguna internet berdasarkan usia, pengguna terbanyak usia 35-44 tahun sebesar 29,2\%. Sedangkan pengguna paling sedikit usia 55 tahun ke atas hanya sebesar $10 \%$. Pengguna internet terbanyak berprofesi sebagai Pekerja / Wiraswasta sebesar 82,2 juta atau $62 \%$. Urutan pengguna internet berikutnya berprofesi sebagai Ibu Rumah Tangga (IRT) sebesar 22 juta atau $16,6 \%$.

Pada dasarnya, literasi sangat berkaitan dengan dunia pendidikan. Di era digital ini, disadari ataupun tidak, tantangan dunia pendidikan ke depan akan lebih berat. Oleh karena itu, optimalisasi teknologi informasi dan komunikasi menjadi salah satu alternatif solusi dalam menopang dan menggerakkan dunia pendidikan di kancah persaingan global. Sebab, yang terjadi saat ini ialah maraknya berbagai macam kasus tentang informasi hoax, yang menyebabkan perpecahan di tengah masyarakat. Permasalahan ini menyebabkan menurunnya kepercayaan publik secara drastis kepada pemerintah (vertikal) dan adanya persepsi saling curiga antarwarga negara (horizontal). Hal ini jika dibiarkan menjadi ancaman. Negara harus hadir mengatasi permasalahan ini. Negara 
harus memastikan bahwa nilai-nilai fundamentalnya telah berjalan dengan baik, sehingga nantinya tidak terjadi hal-hal yang tidak diinginkan. Melalui kajian pendidikan karakter berbasis Pancasila, peneliti mencoba mengkaji secara holistik dan komprehensif terkait dengan bagaimana proses pendidikan karakter Pancasila yang dapat dilakukan di era digital saat ini? Era di mana informasi sangat cepat beredar, era di mana informasi sangat mudah diterima oleh masyarakat, era di mana informasi dapat dengan cepat mempengaruhi pola pikir masyarakat, padahal informasi tersbut bisa jadi ialah informasi yang tidak benar atau informasi hoax.

\section{METODE PENELITIAN}

Penelitian ini menggunakan metode penelitian lapangan dan termasuk jenis penelitian deskriptif kualitatif. Penelitian lapangan memiliki tujuan untuk mempelajari secara intensif tentang latar belakang keadaan sekarang dan interaksi lingkungan suatu unit sosial: individu, kelompok, lembaga atau masyarakat (Creswell, 2016: 245). Peneliti berpendapat bahwa metode ini sesuai dengan maksud dan tujuan penelitian yang pada dasarnya mendeskripsikan tentang bagaimana proses reduksi informasi hoax di era digital melalui pendidikan karakter berbasis Pancasila.

\section{PEMBAHASAN}

\section{Proses Pendidikan Karakter Berbasis Pancasila pada Era Digital}

Pada dasarnya, ada banyak kegiatan yang dilakukan oleh Himpunan Mahasiswa Prodi (HMP) Demokratia yang mana menjadi tempat penelitian ini, namun fokus pembahasan pada penelitian ini pada kegiatan pendidikan karakter yang dilakukan oleh HMP PPKn Demokratia terkait dengan usaha reduksi hoax. Hasil penelitian ini memaparkan bahwa proses pendidikan karakter berbasis Pancasila dilakukan dengan kegiatan peningkatan literasi mahasiswa melalui berbagai kegiatan seperti seminar, FGD, dan kelas kebangsaan.

Teknologi yang modern mengembangkan sarana kebutuhan hidup manusia hampir dari setiap aspek yang berorientasi pada tingkat efisiensi dan efektivitas hingga dapat menghiraukan jarak yang jauh dan waktu yang lama sebagai masalah utama pada perkembangan kehidupan klasik. Teknologi menjawab kebutuhan tersebut dengan melahirkan terobosan aktual yang kini dapat di nikmati oleh setiap golongan masyarakat seperti internet. Internet memiliki keunggulan sebagai jaringan yang dapat menjangkau seluruh pelosok dunia, internet dianggap mampu memenuhi tuntutan masyarakat global dalam 
mewujudkan gaya hidup modern (Saidin, 2004:519).

Permulaan dari revolusi teknologi ini ditandai perkembangan elektronik digital seperti komputer yang semakin hari kinerja dan performanya semakin ditingkatkan hingga memungkinkan transmisi ke teknologi lain seperti kamera, pemutar music, remot. Perkembangan ini mampu diimbanginya dengan perkembangan jaringan komputer berakses internet, munculnya penyiaran digital, dan ponsel berbasis third-generation Technology (3G) yang berkembang erat sejak tahun 2000. Perkembangan tersebut relevan dengan kebutuhan masyarakat modern terkait komunikasi, informasi, koneksi Online berbasis teknologi yang tidak hanya sebatas komputer (Syafari, 2017:2).

Perkembangan teknologi informasi pada saat ini terus menanjak dan tidak dapat diprediksi bagaimana puncaknya. Masyarakat Indonesia tidak kalah ketinggalan dalam persoalan penggunaan teknologi khususnya koneksi internet diikuti dengan data penggunaan internat di Indonesia pada tahun 2018 oleh Asosiasi Penyelenggara Jasa Internet Indonesia (APJII) terhitung mencapai 171 juta orang dari total penduduk 264,14 juta, artinya lebih banyak masyarakat yang memunyai kemudahan mengakses informasi.

\section{Penggunaan}

internet menunjukkan bahwa orang diseluruhi dunia mempunyai pilihan dan fleksibilitas yang bebas untuk dapat masuk dan melakukan apa pun di dalamnya. Internet dapat disebut sebagai sebuah ruang dalam dimensi baru yang berbeda dengan realitas fisik, ungkapan tersebut cocok untuk menyebutkan kompleksitas fenomena yang diciptakan oleh jaringan internet global yang menggunakan infrastruktur telekomunikasi dalam mengirim dan menerima data (Isnaini, 2009:24).

Terciptanya ruangan baru di luar realitas menjadi potensi bagi berkembangnya kepentingan dan kebutuhan tertentu yang bebas dan leluasa seperti kebutuhan politik, kebutuhan ekonomi, dan kebutuhan edukasi. Pada era ini tidak jarang ditemukan sebuah kampanye Online via media sosial yang menunjukkan suatu eksistensi tertentu dari kekuasaan sebagai kepentingan politik, pada tahapan ini telah sukses mempropaganda konsumen internet berdasarkan kepentingannya. Dalam wilayah perekonomian dapat menemukan bursa saham acara Online, data dari aktivitas bisnis bisa didapatkan dengan mudah secara cepat dan aktual, begitu juga dengan proses transaksi bisnis yang kini sudah dapat dilakukan dalam jaringan, seperti kehadiran Marketplace Online dan aplikasi penyedia jasa bisnis. Demikian juga dalam bidang pendidikan, pendidikan cyber masih dalam tahap perkembangan, namun telah ada 
pendahulunya yang menawarkan pendidikan secara Online melalui website seperti Edmodo, elisa, dan webx.

Permasalahan utama dalam kemajuan ini pada kelebihannya itu sendiri, akses tanpa batas yang dapat diperoleh melalui internet melahirkan paradox bagi dilema kehidupan aktual yang sering kali kontradiksi dan memunculkan masalah yang lebih serius. Salah satunya status epistemologis seseorang dalam memahami sesuatu dan meyakini suatu hal dapat terpengaruh dan tersetting oleh hal yang jumlahnya kompleks dan hal tersebut tidak dapat dikendalikan sekalipun oleh pemerintah. Oleh sebab itu internet dapat menurunkan angka kepercayaan kepada orang lain, munculnya rasa saling curiga, dan terjebak pada diri sendiri atau komunitas tertentu. Paradoks internet di tengah kemajuan teknologi modern malah melahirkan manusia-manusia konservatif berdasarkan kelainan dan kegagalan menyerap informasi.

Di era digital seperti saat ini stabilitas karakter warganegara menjadi hal yang terpenting. Hal tersebut disebabkan oleh perkembangan teknologi yang semakin meningkat dan menyebabkan informasi yang benar maupun informasi bohong (hoax) menyebar luas dengan begitu mudah. Tentunya kemajuan teknologi ini dapat dimanfaatkan untuk hal-hal yang baik atau bisa juga sebaliknya, dimanipulasi oleh golongan tertentu demi memenuhi keinginan atau kebutuhan golongan itu sendiri. Kemajuan tekonologi membuat informasi berbasis digital begitu mudah menyebar luas dan simpang siur, oleh sebab itu apabila warganegara tidak memiliki stabilitas karakter atau jati diri yang kuat tentunya akan menimbulkan chaos. Disinilah stabilitas karakter warganegara Indonesia sangat dibutuhkan, mengingat di era digital seperti saat ini akan ada banyak sekali berita yang tidak diketahui validitasnya menyebar luas dengan sangat mudah.

Era digital merupakan zaman dimana dilakukan proses digitalisasi dalam berbagai aspek. Pendidikan karakter adalah suatu upaya membangun karakter, sesuai dengan cita-cita ideologis. Pendidikan karakter merupakan perwujudan dari amanat kebangsaan yang tertuang dalam Pancasila dan UndangUundang Dasar 1945. Pendidikan karakter juga merupakan implementasi dari Undang-Undang Nomor 20 Tahun 2013 tentang fungsi dan tujuan pendidikan nasional yang menyatakan bahwa "pendidikan nasional berfungsi mengembangkan dan membentuk watak serta peradaban bangsa, bertujuan untuk berkembangnya potensi peserta didik agar menjadi manusia yang beriman dan bertaqwa kepada Tuhan Yang Maha Esa, berakhlak mulia, sehat, 
berilmu, cakap, kreatif, mandiri, dan menjadi warganegara yang demokratis serta bertanggungjawab" (Sulistyarini, 2015: 3).

Tugas pendidikan karakter mengembangkan karakter privat dan karakter publik, yang meliputi tanggung jawab moral, disiplin pribadi, hormat kepada orang lain dan martabat manusia, publicspiritedness, civility, respect for law, critical-mindedness, and willingness to negotiate and compromise. Pendidikan karakter mengajarkan kebiasaan cara berpikir dan perilaku yang membantu individu untuk hidup dan bekerja sama sebagai keluarga, masyarakat, dan bernegara dan untuk membuat keputusan yang dapat dipertanggungjawabkan. Dengan kata lain, pendidikan karakter mengajarkan pemuda untuk berpikir cerdas sehingga mampu mengatasi berbagai macam masalah baru yang ada, meningkatkan kemampuan untuk berbaur dengan bangsa lain dengan tetap mempertahankan identitas dan budaya bangsa (Octavia, 2017: 113114).

Pendidikan
Indonesia haruster di
Pancasila sebagai
karakter sumber dari
bangsa. Pancasila
merupakan fondasi filosofis dan
kompas arah tujuan bangsa Indonesia,
dan dalam kedudukan ini, Pancasila
harus dilihat sebagai sumber utama
bagi arah pembangunan bangsa
Indonesia. Pancasila sebagai fondasi

dalam pendidikan karakter bangsa, tidak boleh dimaknai secara terpisahpisah antar tiap sila. Sebab, Pancasila sebagai dasar negara merupakan satu kesatuan dalam arti lahiriah yang oleh Notonagoro disebut kesatuan organis.

\section{Reduksi Informasi Hoax Melalui Pendidikan Karakter Berbasis Pancasila}

Pendidikan adalah transformasi nilai yang menjadikan seorang anak dewasa, artinya seseorang dapat melakukan tindakannya sendiri dengan pertimbangan baik-buruk dan benar-salah yang tepat sesuai konteks dan aturan yang berlaku. Secara formal, dalam UU Nomor 20 Tahun 2003 pendidikan adalah usaha sadar dan terencana untuk mewujudkan suasana belajar dan proses pembelajaran agar peserta didik secara aktif mengembangkan potensi dirinya untuk memiliki kekuatan spiritual keagamaan, pengendalian diri, kepribadian, kecerdasan, akhlak mulia, serta keterampilan yang diperlukan dirinya, masyarakat, bangsa dan negara.

Hasil temuan penelitian ini memaparkan bahwa proses pendidikan karakter dilakukan melalui berbagai macam kegiatan seperti seminar, FGD, dan kelas kebangsaan. Di dalam kelas kebangsaan dilakukan pula pelatihan penangkalan informasi hoax yang dilakukan dengan cara cross check information, dan pendidikan karakter 
yang dilakukan melalui diskusi publik dengan dewan dosen. Hal ini bertujuanuntuk meningkatkan literasi mahasiswa, lebih khususnya lagi sebagai usaha untuk melakukan penangkalan informasi hoax. Literasi mahasiswa yang merupakan warganegara dalam hal berkewarganegaraan umumnya di dunia nyata, khususnya di dunia maya, sangat perlu diperhatikan. Salah satu cara membangun literasi kewarganegaraan tersebut ialah reaktualisasi nilai-nilai Pancasila baik dalam kehidupan nyata maupun kehidupan maya yang pada saat ini sudah menjadi bagian dari kehidupan berwarga negara.

Perkembangan pendidikan masyarakat dari masa ke masa menunjukkan perubahan orientasi berdasarkan pada kondisi zaman saat itu dan pengaruh otoritas yang mengambil keputusan. Secara bertahap tujuan pendidikan di Indonesia mengalami perkembangan dan penyesuaian dengan zaman, sasaran utama dari tujuan tersebut sebagai sumber hukum tertinggi bagi setiap lembaga pendidikan di Indonesia yang didasari oleh Pancasila sebagai landasan filosofis (seharusnya) mempunyai pengaruh yang dominan. Berdasarkan UndangUndang, tujuan pendidikan cenderung kontekstualisasinya tanpa merubah esensinya sebagai upaya mencerdaskan kehidupan bangsa.
Perkembangan pendidikan pada saat ini berpusat pada peningkatan sumber daya manusia yang unggul dan mempunyai daya pembangunan yang sehat, artinya produktivitas menjadi orientasi utama keberhasilan pendidikan nasional khususnya yang dilahirkan oleh perguruan tinggi. Hal ini ditegaskan oleh Muhadjir Effendy sebagai menteri pendidikan dan kebudayaan dalam pidatonya pada saat perayaan upacara kemerdekaan 17 Agustus 2018, yakni:

Upaya untuk meningkatkan kualitas SDM harus dilihat dari dua perspektif: manusia sebagai insan yang berkarakter unggul dan manusia sebagai sumber daya pembangunan yang sehat, berpendidikan, dan produktif. Untuk itu terdapat lima karakteristik SDM yang perlu dihasilkan melalui pendidikan dan kebudayaan, yaitu: 1) Memiliki karakter kuat; 2) Memiliki multikecakapan Abad 21 dan Bersertifikat; 3) Elastis dan Pembelajar Sepanjang Hayat; 4) Inovatif dan Kewirausahaan; 5) Kewargaan Global.

Berdasarkan pidato tersebut, dapat diketahui bahwa sasaran utama pendidikan merupakan potensi dasariah manusia yang diarahkan pada tujuan tertentu, yakni karakteristik ideal yang mampu mengangkat keberhasilan dan kemajuan negara terutama dalam persaingan ekonomi dan tenaga kerja menghadapi era disrupsi dan revolusi 
industri 4.0. Namun kenyataannya upaya meningkatkan kualitas SDM saja tidak cukup, warganegara yang terikat pada nilai-nilai tradisi, identitas dan religi perlu dihimpun perkembangannya karena yang dibutuhkan bukan hanya kesejahteraan. Sebagaimana Pancasila, kepribadian dan kedewasaan warga negara membutuhkan religiusitas, kemanusiaan yang luhur, toleransi berbangsa, keterbukaan antar masyarakat, dan pemerataan hak, ke lima poin tersebut seharusnya dapat diimplementasikan oleh pendidikan yang mempunyai simultan subur terkait berkembangnya nilai-nilai religi, kerja keras, gotong-royong, kebangsaan dan sebagainya.

Perkembangan teknologi yang menawarkan kemudahan dalam komunikasi dan informasi berpengaruh pada perkembangan pendidikan di Indonesia. Berdasarkan itu proses penyampaian nilai-nilai dari pendidik ke peserta didik yang mulai dikenalkan digitalisasi atau proses pendidikan berbasis digital dengan menggunakan media Online sebagai sarana pendidikan. Program tersebut didesain agar penyampaian informasi didukung oleh kemudahan dan konsep yang diberikan oleh pendidik semakin cepat direalisasikan oleh peserta didik. Metode tersebut menuntut pendidikan untuk lebih leluasa menyesuaikan diri dengan zaman agar melahirkan suatu generasi yang berkualitas di persaingan ekonomi dan kerja. Program tersebut sudah menjadi gagasan dalam membangun kebijakan, sebagaimana dalam pidato Menristek Mohammad Nasir pada peringatan Hardiknas 2018:

Menghadapi revolusi industri 4.0, Kemenristekdikti sudah bergerak. Kami menggagas beberapa kebijakan untuk menjawab kebutuhan di era ini. Salah satu kebijakan yang akan segera diimplementasikan Program Pendidikan Jarak Jauh atau PJJ, di mana dalam waktu dekat Kemenristekdikti akan mengeluarkan permenristekdikti untuk mendukung pelaksanaan program ini. Adapun salah satu implementasi dari kebijakan mengenai PJJ nantinya adalah pembangunan universitas siber (Cyber University) yang dipersiapkan untuk pembelajaran daring (Republik Indonesia, 2018: 5).

Walaupun masih dalam perkembangan untuk mensectralisasi pendidikan berbasis cyber, namun akan terlihat banyak permasalah terkait penggunaan internet khususnya pada pendidikan karakter. Seperti bagaimana mungkin suatu tulisan, gambar, dan video yang ditampilkan pada layar kaca dapat mengatur dan menentukan tindakan seseorang agar menjadi dewasa dan bahkan menjadi Pancasilais? Pendidikan cyber bukan hanya persoalan wilayah cyber yang digunakan, akan tetapi efektivitas dan dampak dari pendidikan itu sendiri 
apakah suda terlaksana dengan baik pada realitas fisik sebelum atau sesudah adanya internet. Oleh sebab itu digitalisasi merupakan proses mempermudah akses dalam mentransfer informasi, sedangkan untuk transfer nilai dibutuhkan suatu prosedur yang berkelanjutan dan konsistensi yang kuat agar program tersebut dapat bertahan.

Tantangan lebih lanjut dari perkembangan pendidikan khususnya era digital adalah mampu menanamkan karakter kebangsaan dan melahirkan jiwa bernegara yang tinggi dengan memberikan informasi yang valid, kuat dan terpercaya sehingga masyarakat meyakini terdapat kebenaran dalam diri mereka yang dapat dipegang dan dipertahankan. Oleh karenaitu, pendidikan yang berhasil yaitu pendidikan yang mampu membangun kepercayaan terhadap negara sehingga negara selalu mendapat dukungan dari warganegaranya, bukan cemoohan dan rasa curiga yang dihasilkan. Namun tujuan tersebut berkebalikan dengan kenyataan kepentingan politik dalam memanfaatkan teknologi informasi dengan sengaja mengembangkan Post-truth menjadi alat propaganda dengan tujuan mengolah sentimen masyarakat sehingga bagi yang kurang kritis akan dengan mudah terpengaruh yang diwujudkan dalam bentuk empati dan simpati terhadap agenda politik tertentu yang sedang diskenariokan (Cahyono, 2018).
Informasi hoax dapat dikatakan sebagai berita bohong, yang diproduksi guna melegitimasi kepentingan pribadi. Persebaran hoax biasanya melalui media-media informasi baru, atau yang lebih dikenal dengan media sosial (facebook, whatssapp, twitter, instagram, youtube, dan sebagainya). Hoax bertujuan terutama untuk menumbangkan kebenaran, dengan bersembunyi dibalik kebohongan.

Hoax biasanya bukanlah sebuah bentuk kesalahan yang tidak disengaja untuk berbohong. Hoax merupakan suatu bentuk manipulasi informasi dengan sadar, entah disebabkan oleh ketidaktahuan yang disengaja, atau dengan intensi untuk melakukan penipuan. Hoax biasanya suatu bentuk produksi informasi palsu yang secara sengaja dibuat untuk menipu publik. Hoax berkaitan erat dengan politik, sebab hoax merupakan salah satu senjata politik untuk melegitimasi ideologi atau kepercayaan seorang politisi.

Hoax adalah implikasi dari sifat dasar manusia yang mementingkan dirinya sendiri. Manusia telah memasuki era fungsional, di mana ia akan melakukan segala sesuatu, jika dan hanya jika tindakan tersebut membawa keuntungan padanya. Relasi manusia dengan kenyataan menjadi penting, hanya jika ada kepentingan. Oleh karenanya manusia fungsionil merasa bebas 
untuk melakukan apa saja, terlepas dari pertanggungjawabannya kepada dunia dan realitas.

Produksi hoax di era posttruth dapat berkembang pesat secara umum disebabkan oleh 2 faktor utama. 1). Adanya Knowledge Devide atau kesenjangan pengetahuan antara teknologi informasi dan pemanfaatannya. 2). Adaptasi regulasi (hukum) dengan perkembangan teknologi informasi yang tidak sebanding. Untuk itu, dalam upaya menekan produksi berita hoax, harus terlebih dahulu mengejar ketertinggalan pengetahuan antara teknologi dan pemanfaatannya. Kedua mengejar ketertinggalan regulasi, dengan menyusun regulasi yang memadai terkait teknologi informasi dan penggunannya.

\section{SIMPULAN DAN SARAN}

\section{A. Simpulan}

Bahwa proses pendidikan karakter berbasis Pancasila di era digital dapat dilakukan dengan kegiatan peningkatan literasi mahasiswa melalui berbagai kegiatan seperti seminar, FGD, dan kelas kebangsaan. Proses pendidikan karakter berbasis Pancasila di era digital ini pada dasarnya sangat diperlukan. Literasi warga negara dalam hal berkewarganegaraan umumnya di dunia nyata, khususnya di dunia maya, sangat perlu diperhatikan. Salah satu cara membangun literasi kewarganegaraan tersebut ialah reaktualisasi nilai-nilai Pancasila baik dalam kehidupan nyata maupun kehidupan maya yang pada saat ini sudah menjadi bagian dari kehidupan berwarganegara.

Di era serba digital seperi saat ini informasi dapat menyebar luas dengan begitu cepat dan cenderung sulit untuk dikendalikan. Banyak sekali informasi yang bertebaran di seluruh media massa yang membuat masyarakat rancu dan sulit membedakan mana informasi yang benar dan valid, mana informasi yang validitasnya masih dipertanyakan. Tentunya hal tersebut sangat wajar mengingat kemajuan teknologi menunjang mudahnya informasi menyebar luas tanpa adanya penyaringan terlebih dahulu. Hal tersebut menjadi tantangan tersendiri bagi warga negara maupun penyelenggara negara untuk mengahadapi berbagai informasi yang simpang siur di era digital seperti saat ini. Untuk itu, bagaimana negara mampu tetap menjaga stabilitas keamanan dan pertahanan negara di tengah-tengahnya banyaknya informasi hoax yang begitu mudah menyebar luas. Para penyelenggara negara juga akan menemukan kesulitan untuk menanggulangi banyaknya informasi hoax yang begitu mudah menyebar luas.

Proses mereduksi informasi hoax dilakukan dengan cara cross 
check information, dan pendidikan karakter yang dilakukan melalui diskusi publik dengan dewan dosen. Literasi warganegara dalam hal berkewarganegaraan umumnya di dunia nyata, khususnya di dunia maya, sangat perlu diperhatikan. Salah satu cara membangun literasi kewarganegaraan tersebut ialah reaktualisasi nilai-nilai Pancasila baik dalam kehidupan nyata maupun kehidupan maya yang pada saat ini sudah menjadi bagian dari kehidupan berwarganegara. Adapun yang dilakukan memperkuat karakter melalui pendidikan karakter berbasis Pancasila dapat dijadikan sebagai salah satu cara jangka panjang agar dapat terhindar menjadi korban informasi hoax. Nilai-nilai yang terkandung didalam sila-sila Pancasila merupakan nilai-nilai luhur yang sesuai dengan karakter bangsa ini, mengingat Pancasila merupakan representasi negara yang digali dari dalam diri bangsa ini. Pendidikan karakter berbasis Pancasila ini tentunya harus dilaksanakan dan diberikan sedini mungkin sehingga setiap warganegara siap menghadapi perkembangan zaman dengan tetap mampu mempertahankan karakteristik yang Pancasilais.

\section{B. Saran}

Bahwa pada prinsipnya kegiatan pengembangan literasi tentang Pancasila perlu terus dilakukan. Diskursus tentang Pancasila yang mendalam sangat perlu dikembangkan sebagai upaya untuk menangkal dampak buruk dari perkembangan teknologi informasi dan komunikasi di era globalisasi. 


\section{DAFTAR PUSTAKA}

Asosiasi Penyelenggara Jasa Internet Indonesia (APJII). (2016). Infografis Penetrasi dan Perilaku Pengguna Internet ndonesia. Polling Indonesia. Copyright@APJII 2016.

Cahyono, Edi. 2018. Media sosial-post truth. http://ksp.go.id/media-sosial-post truth-dan-literasi digital/index.html. Diakses Pada Tanggal 10 Juni 2019.

Creswell, J., W., 2016.Research Design: Pendekatan Metode Kualitatif, Kuantitatif, dan Campuran Edisi Keempat. Yogyakarta: Pustaka Pelajar.

Isnaini, Yusran. 2009. Hak Cipta dan Tantangannya di Era Cyber. Jakarta: Ghalia Indonesia.

Mandala, Rila \& Hendra Setiawan (2002). "Peningkatan performansi sistem temu kembali informasi dengan perluasan query secara otomatis". Proceeding the 3rd Annual Meeting of the Indonesian Digital Librray Networks. Establishing Cooperation to a Networked Information Society, Bandung: Tim KMRG-ITB.

Octavia, Erna, dan M. Anwar Rube'i. 2017. Penguatan Pendidikan Karakter Berbasis Pancasila untuk Membentuk Mahasiswa Prodi PPKN Menjadi Warga Negara yang Baik dan Cerdas. Sosial Hori-zon: Jurnal Pendidikan Nasional, Vol. 4, No. 1, Juni 2017, Hal: 111-124.

Republik Indonesia, 2018. Pidato Menteri Pendidikan dan Kebudayaan RI, Peringatan Hari Pendidikan Nasional, 2 Mei 2018. Jakarta: Menteri Pendidikan dan Kebudayaan Republik Indonesia.

Saidin, O.K. 2004. Aspek Hukum Hak Kekayaan Inelektual. Jakarta: Raja Gravido Persada.

Sulistyarini. 2015. Perkembangan Karakter Berbasis Pancasila Melalui Pendidikan Kewarganegaraan. Jurnal Bhineka Tunggal Ika, Vol. 2, No. 1, Mei 2015, Hal: 1-8.

Syafari, Anjar. 2017. Sekilas Tentang Teknologi 3G. Copyright (C) 2003-2007 IlmuKomputer.Com 